\title{
Benthic Diatom Composition of Iztuzu Coastal Lake, Dalyan (Aegean Sea, Turkey)
}

\author{
Aydın Kaleli' ${ }^{1}$ (]
}

Cite this article as: Kaleli, A. (2019). Benthic diatom composition of Iztuzu Coastal Lake, Dalyan (Aegean Sea, Turkey). Aquatic Sciences and Engineering, 34(4), 122-130.

ORCID IDs of the authors: A.K. $0000-0003-3843-1335$

1'Istanbul University, Faculty of Aquatic Sciences, Department of Freshwater Resource and Management, İstanbul, Turkey

Submitted:

11.06.2019

Accepted:

10.09.2019

Online published:

30.09.2019

Correspondence:

Aydın Kaleli

E-mail:

aydin.kaleli@istanbul.edu.tr

CCopyright 2019 by Aquatic Sciences and Engineering Available online at

https://dergipark.org.tr/ase

\begin{abstract}
Coastal lakes are shallow lakes that have variable characteristics through fluctuations and marine winds. In this study, benthic diatom composition in the coastal lake of Iztuzu, Dalyan of Muğla was investigated from the material collected in 2011 and 2015. Little research has been done on coastal lakes and lagoon diatom flora in Turkey; this study contributes a total of 49 taxa identified to species level and 9 of the taxa for the first time recorded for diatom flora of Turkey. The most abundant taxa were; Cocconeis placentula Ehrenberg, Diploneis bombus (Ehrenberg) Ehrenberg, Mastogloia sp. and Chamaepinnularia alexandrowiczii Witkowski, Lange-Bertalot and Metzeltin. The results reveal a habitat-specific flora for Iztuzu Lake and give an aspect of understanding the marine-brackish distribution of diatoms in coastal lakes and lagoons. The results extend the knowledge of marine and brackish diatoms in Turkey and could provide data for similar lagoon and lakes which are under protection.
\end{abstract}

Keywords: Benthic, diatoms, coastal lake, Iztuzu, Dalyan, Turkey

\section{INTRODUCTION}

Diatoms are unicellular silicious photosynthetic algae and distributed to a wide range of areas where water exists; from marine coasts to high mountain lakes and springs, cave entrances to thermal springs and even as epibionts on marine mammals (Denys, 1997; Aysel, 2005). Diatoms are also good indicators of ecological changes in lakes and streams, which are used to monitor the status of the location with a supplement of physiochemical parameters (Şanal \& Demir, 2018).

Coastal lakes have very dynamic hydrology and are affected by variable environmental conditions. Marine winds, sea spray or sea flooding cause mixing events which result in high productivity in these lakes (Hansson \& Håkansson, 1992). Salinity can change more in some lakes where there are stream openings and freshwater inputs (Gasparon \& Burgess, 2000). The sur- rounding environment could influence coastal lakes and lagoons. Salinity and water temperature differences in the lagoon and lakes of the Black Sea and the Mediterranean Sea affects flora and fauna as well (Yerli, 1999). Coastal lakes and lagoons are important habitats due to the rapid changes in salinity and productivity, in response to an ideal location to observe ecological changes; however, the mentioned reasons make these areas sensitive to pollution. There were several studies in the lakes and lagoons, e.g., taxonomic studies including the discovery of new diatoms (Giffen, 1967; Riaux-Gobin \& Compère, 2009) and diatoms used as environmental indicators (Desianti et al., 2017).

Several studies were carried out on the benthic and planktonic flora of diatoms in coastal lakes and lagoons in Turkey. Sıvacı, Yardım, Gönülol, Bat \& Gümüş (2008) studied the benthic algae 
composition of Sarıkum Lagoon; epipelic algae was studied at Balık and Uzun Lagoon (Gönülol, Ersanlı \& Baytut, 2009), while Soylu, Maraşlıoğlu \& Gönülol (2011) focused on the epiphytic diatoms of Liman Lake in the Black Sea coasts. In the Sea of Marmara region, Polge, Sukatar, Soylu \& Gönülol (2010) studied epipelic algae diversity of Küçükçekmece Lagoon. The Aegean Sea and the Mediterranean Sea coastal lake and lagoon planktonic and benthic diatom community was a subject of several studies (Egemen et al., 1999; Çevik, Polat \& Dural, 2008; Aslan et al., 2018).

This study aims to reveal the diatom biodiversity of Iztuzu Coastal Lake in Dalyan; contribute to the knowledge of diatom flora of Turkey. The study documents diatoms and its distribution in a protected and undisturbed area and aims to provide data for further studies, particularly in the coastal lakes and lagoons of Turkish coasts.

\section{MATERIALS AND METHODS}

Iztuzu Lake (Tuz Lake) located in the southwest of Muğla Province at southeast Aegean Sea coasts of Turkey. The hills surround the lake on the east, and the lake is 100 meters inside of the shore of Iztuzu beach. The depth of the lake reaches approximately a meter and has a sand bottom structure (Figure 1). Iztuzu beach is one of the most important nesting locations for loggerhead sea turtles with high numbers of nests and hatchlings in the Mediter- ranean Sea (Margaritoulis et al., 2003). Beach is under the protection, and conservation studies are carried out by Dekamer (Sea Turtle Research, Rescue and Rehabilitation Center) (Başkale \& Kaska, 2005; Kaska, Başkale, Katılmış, Sözbilen \& Azmaz, 2016). Sampling was performed in 2011 and 2015, in 2011 samples were taken from the sand at the bottom of the lake at station 1, and the rocks and stones were scrapped in 2011 and 2015 from all stations. Environmental parameters were measured by Hach HQ40d in 2015; Salinity was 23.4 psu, conductivity was 40.8 mS/ $\mathrm{cm}$, and the water temperature was $30.2^{\circ} \mathrm{C}$.

The Samples were treated with $10 \% \mathrm{HCl}$, boiled with $35 \% \mathrm{H}_{2} \mathrm{O}_{2}$ to remove the organic material and washed with distilled water several times (Swift, 1967). Permanent slides were prepared with airdried cleaned valves and mounted with Naphrax®. Light microscopy observations were performed with Nikon Eclipse Ci-E microscope. At least 200 valves were counted in each material.

Terminology and the taxonomical classification followed Round et al. (1990), DiatomBase (Kociolek et al., 2019) and AlgaeBase (Guiry \& Guiry, 2019). Diatom identification was performed according to the following research; Peragallo \& Peragallo (18971903), Hendey (1964), Giffen (1967, 1976), Simonsen (1987), Snoeijs (1993), Snoeijs \& Balashova (1998), Witkowski, Lange-Bertalot \& Metzeltin (2000), Louvrou (2007), Wachnicka \& Gaiser (2007), Hofmann, Werum \& Lange-Bertalot (2011), Loir \& Novarino

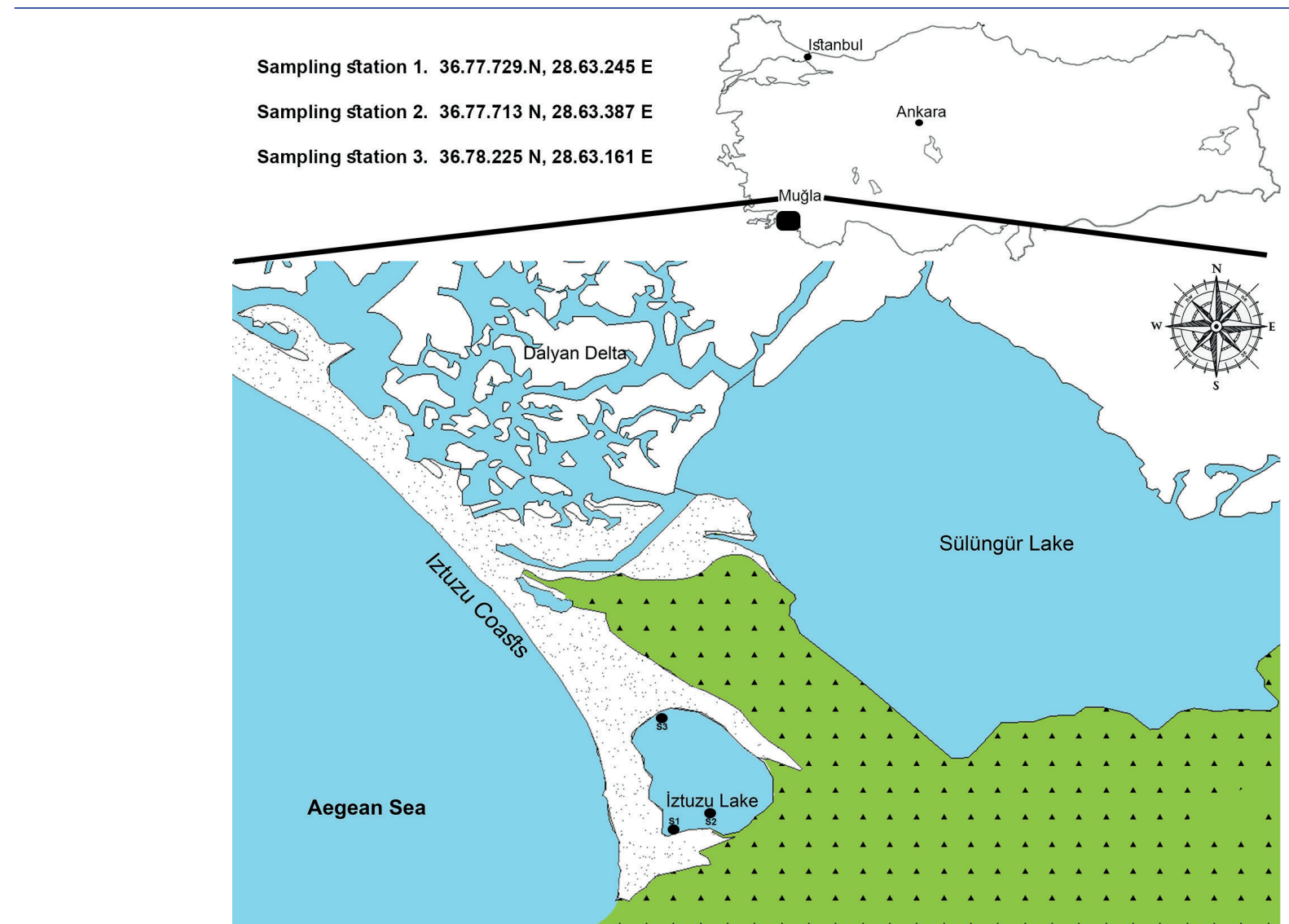

Figure 1. Sampling area of Iztuzu Lake, Dalyan, Muğla. 
Table 1. Distribution of the benthic diatom composition of Iztuzu lake in 2011 and 2015. Habitat information; M: marine, B: brackish, F: freshwater (Guiry \& Guiry, 2019; Kociolek et al., 2019). *asterisk indicates the taxa first time observed in Turkey.

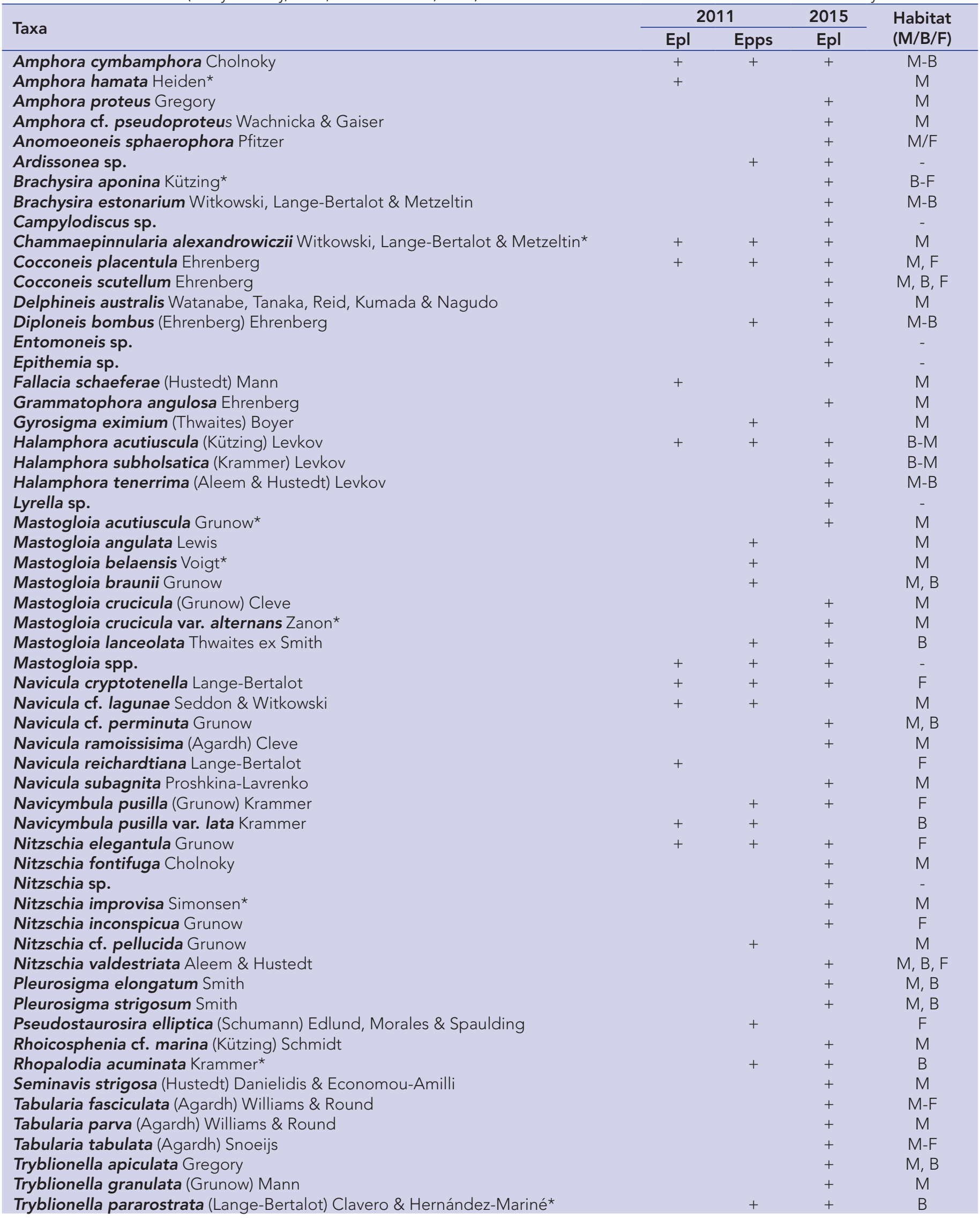


(2014). Diatom distribution in Turkey was compared with Maraşlıoğlu \& Gönülol (2019). Slides and processed materials are deposited at the Department of Freshwater Resource and Management, Aquatic Sciences Faculty, Istanbul University.

\section{RESULTS AND DISCUSSION}

Benthic diatom biodiversity and the changes in the flora throughout the years were investigated in Iztuzu coastal Lake of Dalyan. Forty-six diatom taxa identified to species level. Amongst the genera, Mastogloia was represented with the highest numbers of taxa (8), followed by Nitzschia (7), Navicula (6) and Amphora (4). Although being the most abundant taxa in the composition Cocconeis was represented by two species. In total the most abundant species were Cocconeis placentula (22.38 \%), Masto- gloia sp.1 (15.31 \%) Diploneis bombus (14.58 \%) and Chamaepinnularia alexandrowiczii (13.86 \%) respectively. These former dominant taxa composed $66.13 \%$ of the diatom composition in the lake. The most abundant species in the epipsammon were $C$. placentula, C. alexandrowiczii, Nitzschia elegantula and D. bombus. Furthermore, in epilithic samples, D. bombus, C. placentula and Nitzschia sp. occurred abundantly (Table 1).

Between the sampling years, there was a significant difference occurred in the observed taxa numbers. In 2011, a total of 25 taxa were observed while 48 taxa were found in 2015. Some of the species occurred in both of the samples. These taxa were Cocconeis placentula, Chamaepinnularia alexandrowiczii and Diploneis bombus, and Navicymbula pusilla, Navicula sp., Nitzschia elegantula as well. However, some of the taxa decreased in numbers in
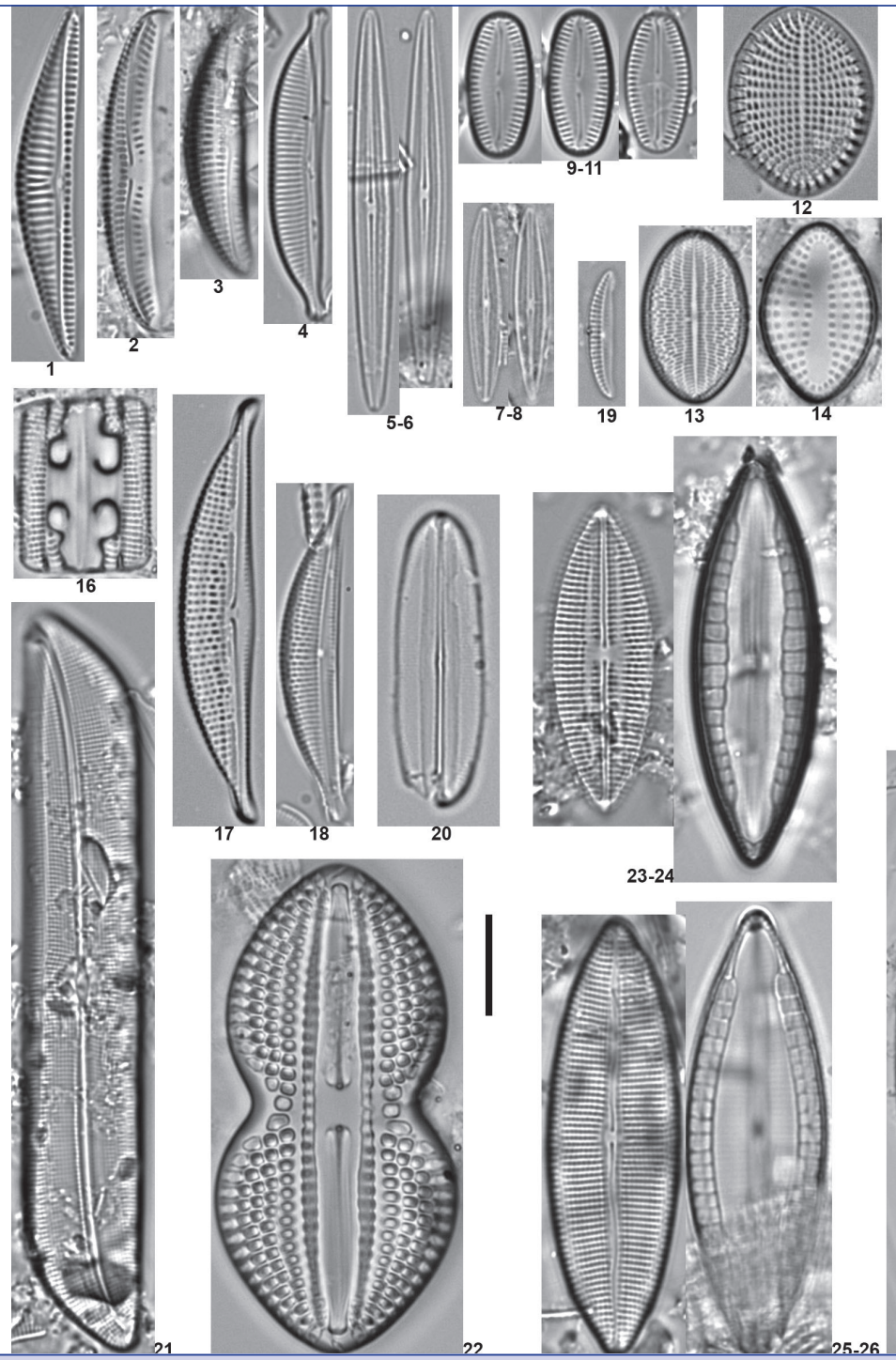

23-24
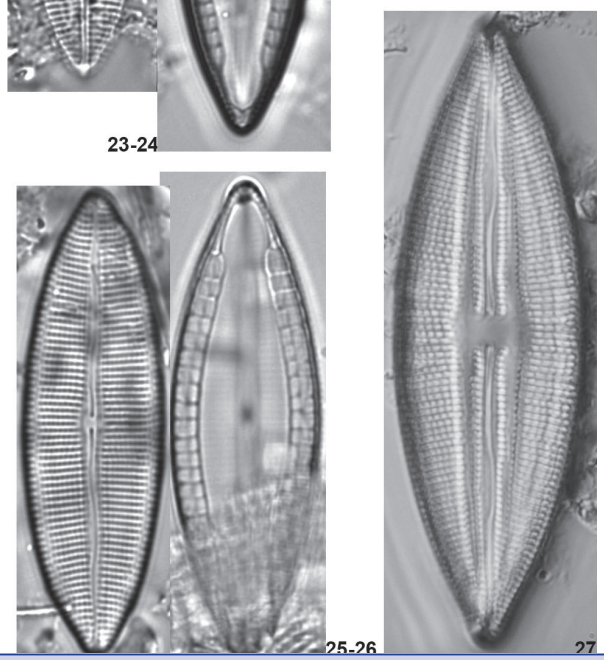

Figure 2. 1. Amphora cymbamphora, 2. A. proteus, 3. A. cf. pseudoproteus, 4. A. hamata, 5, 6. Brachysira aponina, 7, 8. B. estonarium, 9-11. Chamaepinnularia alexandrowiczii, 12. Cocconeis scutellum, 13. C. placentula, 14. Delphineis australis, 15. Anomoeoneis sphaerophora, 16. Grammatophora angulosa, 17. Halamphora subholsatica, 18. H. acutiuscula, 19. H. tenerrima, 20. Fallacia schaeferae, 21. Gyrosigma eximium, 22. Diploneis bombus, $23,24$. Mastogloia braunii, 25, 26. M. acutiuscula, 27. M. belaensis. Scale bar: $10 \mu \mathrm{m}$. 
2015 samples; e.g., C. placentula, C. alexandrowiczii, Mastogloia sp.1, N. pusilla, N. elegantula. Eleven taxa which were recorded in the 2011 samples did not occur in the 2015 samples, e.g., Amphora hamata, Fallacia schaeferae, Gyrosigma eximium, Mastogloia angulata, M. belaensis, M. braunii, Navicula cf. lagunae, N. reichardtiana, Navicymbula pusilla var. lata, Nitzschia cf. pellucida, and Pseudostaurosira elliptica (Figure 2-4).

The results revealed that nine taxa contributed to the knowledge of benthic diatoms in Turkey and were recorded for the first time. These were; Amphora hamata, Brachysira aponina, Chamaepinnularia alexandrowiczii, Mastogloia belaensis, M. acutiuscula, M. crucicula var. alternans, Nitzschia improvisa, Rhopalodia acuminata, and Tryblionella pararostrata.

Coastal lakes, lagoons and transitional waters are very diverse habitats and are composed of challenging environmental conditions. Diatoms are good examples of adaptation to the variable conditions, and it is possible to observe high biodiversity; marine, brackish and freshwater diatoms could occur altogether. Here in this study, 49 taxa were observed in Iztuzu Lake, and 9 of them were recorded for the first time in Turkey. Since Iztuzu Lake is separated from the sea via dunes and inputs of seawater by tides and wave sprays which occur during winter and early spring,
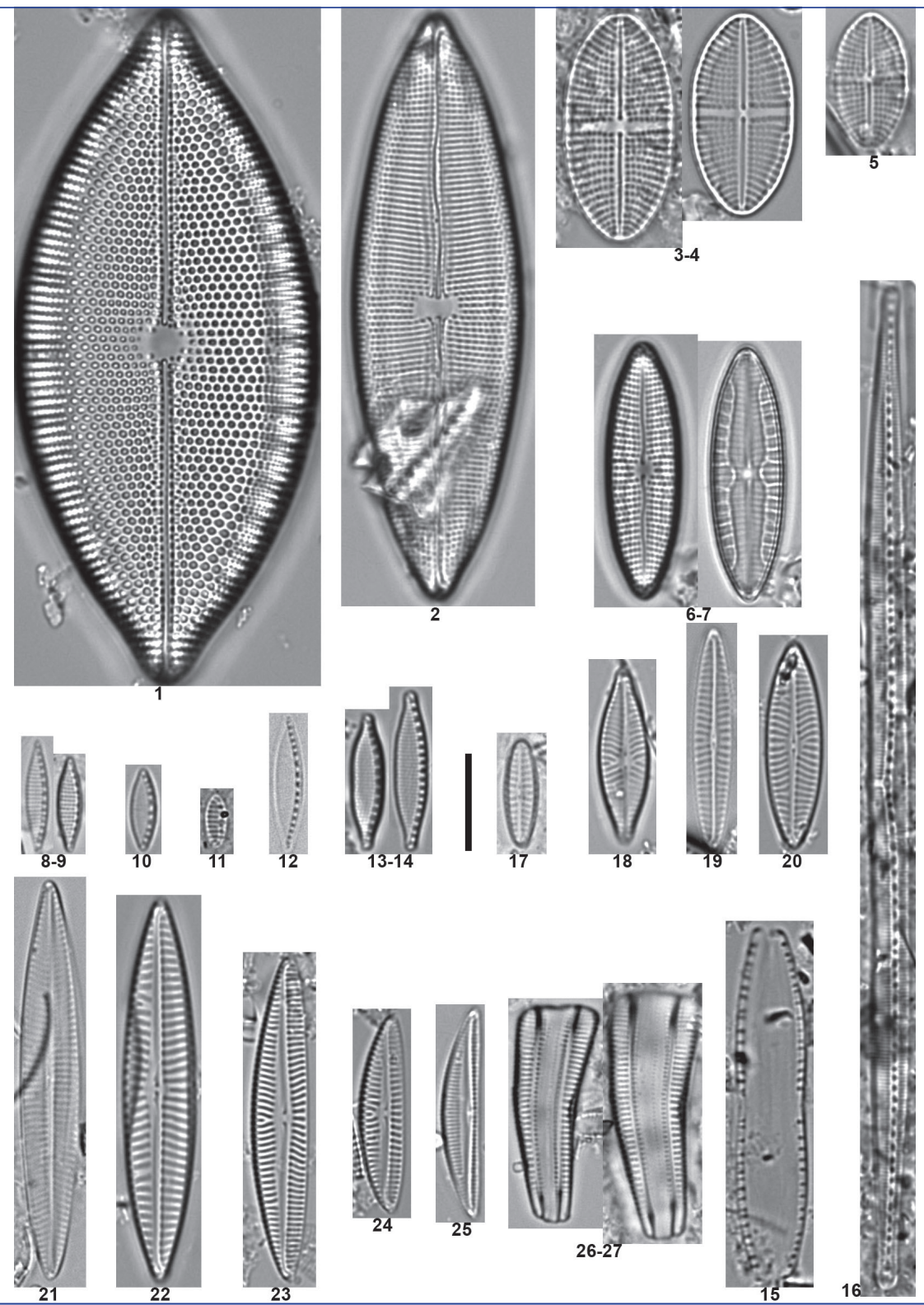

Figure 3. 1. Mastogloia angulata, 2. M. lanceolata, 3, 4. M. crucicula, 5. M. crucicula var. alternans, 6, 7. M. sp1., 8, 9. Nitzschia sp., 10. N. inconspicua, 11. N. valdestriata, 12. N. fontifuga, 13, 14. N. elegantula, 15. N. cf. pellucida, 16. N. improvisa, 17. Navicula cf. perminuta, 18. N. reichardtiana, 19. N. ramoissisima, 20. N. cryptotenella, 21. N. subagnita, 22. N. cf. lagunae, 23. Navicymbula pusilla, 24. N. pusilla var. lata, 25. Seminavis strigosa, 26-27. Rhoicosphenia cf. marina. Scale bar: $10 \mu \mathrm{m}$. 
both freshwater and brackish species were observed as well as marine taxa. However, the marine and the brackish taxa were dominant in benthic diatom composition. The results were compared with the coastal diatom samples, and Sülüngür Lake (unpublished data) and similar freshwater and brackish-freshwater taxa were typical in Sülüngür Lake (e.g., B. aponina, C. placentula, N. elegantula, R. acuminata), and some taxa (D. bombus, Grammatophora angulosa, N. pusilla var. lata) were also observed in coastal samples (Kaleli et al., pers. obs.). It is remark- able that species recorded for the first time from the coastal samples (Amphora cymbamphora, Brachysira estoniarum, F. schaeferae, Mastogloia crucicula) were also observed in Iztuzu Lake, which is a possible transfer of taxa from the marine waters to the brackish lake.

In Turkey, some lagoons and coastal lakes were investigated in terms of the composition of Bacillariophyta (Sivacı et al., 2008; Soylu et al., 2011; Çolak-Sabancı, 2012; Aslan et al., 2018). Re-
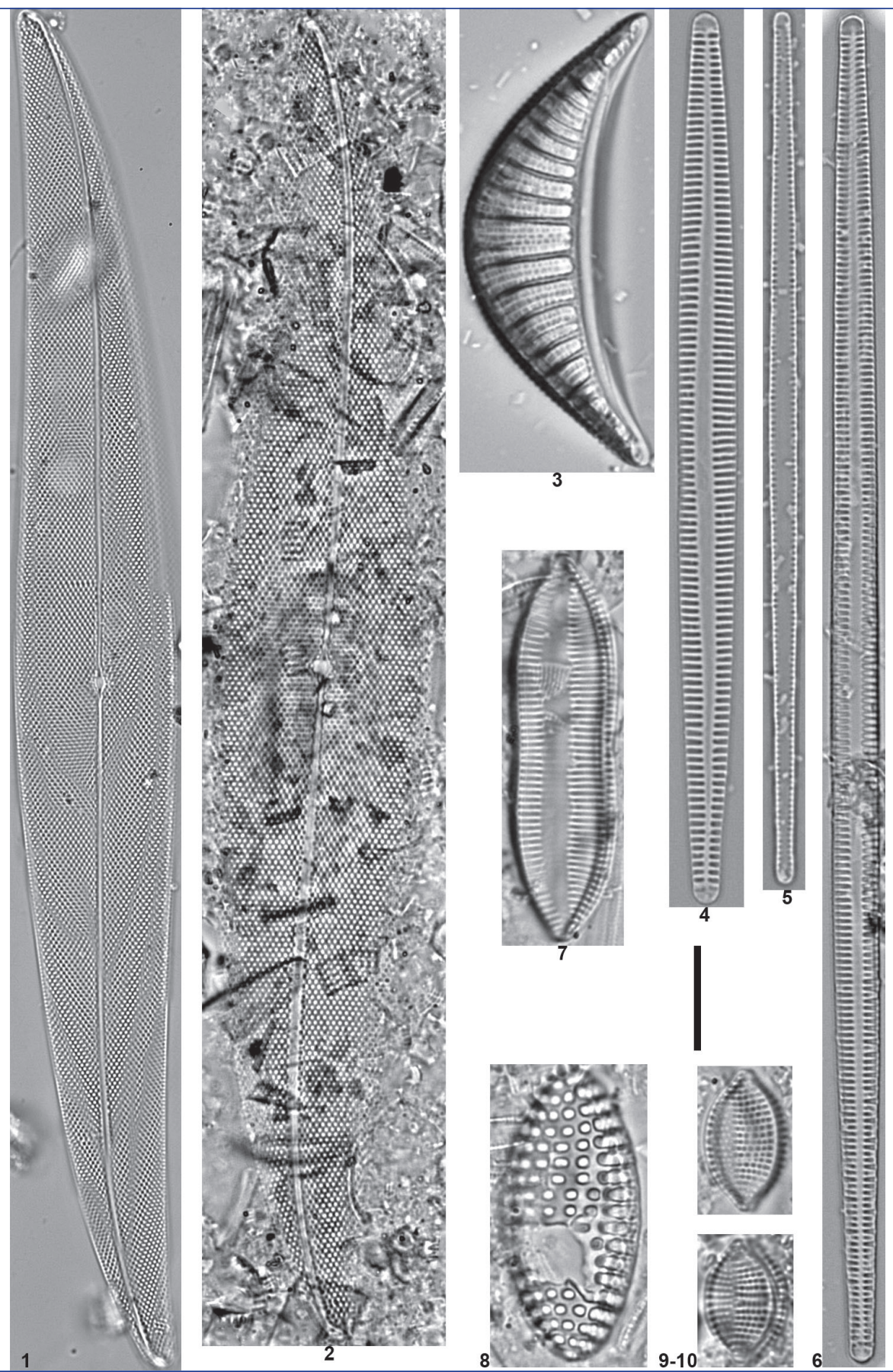

Figure 4. 1. Pleurosigma elongatum, 2. P. strigosum, 3. Rhopalodia acuminata, 4. Tabularia fasciculata, 5. T. parva, 6. T. tabulata, 7. Tryblionella apiculata, 8. T. granulata, 9-10. T. pararostrata. Scale bar: $10 \mu \mathrm{m}$. 
search determined that diatom diversity of other lakes have less common taxa compared to each other, possibly similar to adjacent coastal or river habitats. Sivacı et al. (2008) found 64 taxa and Soylu et al. (2011) recorded 30 taxa in the Black Sea coastal lakes. Authors observed predominantly freshwater taxa, including species of Cymbella, Gomphonema; however, high biodiversity of diatoms was recorded in the lagoons in different regions (Giffen, 1976; Park, Lobban \& Lee, 2018). The diatom composition of Akyatan and Tuzla Lagoons (Çevik et al., 2008) resembles the results found in this study with 42 marine and brackish taxa observed. Çolak-Sabancı (2012) reported 67 diatom taxa (Cocconeis, Mastogloia, Nitzschia) with common brackish and marine species from Homa Lagoon, located in the Aegean coasts of Turkey. Furthermore, research conducted by Aslan et al. (2018) revealed that 34 benthic diatom taxa composed of freshwater-brackish species were found in a coastal salt lake in Gökçeada, Aegean Sea.

Diatom composition in coastal lakes may be affected by sprays of seawater. However, the previous research showed that freshwater input could be more important to shape diatom assemblages in coastal lakes (Soylu et al., 2011). As a result of the fluctuations, brackish taxa could adapt to these conditions. Geographical differences are also crucial for the distribution of species in coastal lakes. Liman and Sarıkum Lakes, located in Black Sea region, have been influenced mainly by rivers (e.g., Kızılırmak River), and floodwater, only a few marine taxa were observed in these lakes (Sivacı et al., 2008; Soylu et al., 2011). Nevertheless, low salinity of the Black Sea is suitable for marine and marine-brackish species to establish a community (Baytut \& Gönülol, 2016; Kaleli, Kulikovskiy \& Solak, 2017). Diatom flora of the two Black Sea lagoons revealed that both lakes were influenced mostly by the freshwater inputs. On the other hand, in the coastal lakes and lagoons of the Aegean Sea and the Mediterranean Sea, more various diatom composition was recorded. Seventeen taxa were marine, and the remaining were brackish and freshwater species found in Akyatan and Tuzla Lagoons in the Mediterranean Sea (Çevik et al., 2008). In Homa Lagoon, 44 of the total 67 taxa were marine species (Çolak-Sabancı, 2012). These results are nearly the opposite of the marine species observed in the Black Sea lagoon, where only five taxa were marine in Sarıkum Lagoon (Sivaci et al., 2008). Biodiversity of the diatoms and marine taxa abundance could be conducted with the effects (sea spray) of the saline waters of the Aegean and the Mediterranean Sea, as well as that; both lagoons were under pressure by agriculture which may have lead to high diversity in terms of organic matter release. Unlike, Akyatan, Tuzla and Homa Lagoons, Iztuzu Lake is covered by the hills and due to the area being protected, there are no settlements and agriculture in the surroundings. It could be a reason for the diatom composition, and the diversity of the taxa remained balanced and not influenced by anthropogenic effects over the years.

Diatom identification is somewhat difficult due to the close taxonomic characters amongst similar taxa or can be overlooked because of the small cell size. Scanning Electron microscopy (SEM) could distinguish the taxa where light microscopy (LM) can be insufficient. It was found out that some small celled taxa can be in- discernible in LM like the genus Olifantiella in the Black Sea coasts of Sinop. However, SEM images revealed that two taxa existed in the material; $O$. pseudobiremis, and $O$. cf. mascarenica (Kaleli et al., 2018). In the taxonomical perspective, several taxa found in this study needs further observation. Some species were rarely found in the material, and there would be more valves needed to see the morphological variation. For instance; Amphora cf. proteus, Navicula cf. perminuta and Rhoicosphenia cf. marina specimens were represented with few valves therefore identified as "cf." due to lack of distinguishing features of each taxon. Navicula cf. lagunae conforms well with descriptions by Seddon, Froyd \& Witkowski (2011); with the presence of the Voigt discontinuity and asymmetrical central area. Similar taxa Navicula flagellifera Hustedt has 12-18 striae in $10 \mu \mathrm{m}$ (Witkowski et al., 2000) comparing to $N$. lagunae, which has 10-11 striae (Seddon et al., 2011). The valves observed in Iztuzu Lake have 11 striae. Specimens found here presumably belong to $N$. lagunae. However, better LM or possible SEM images would contribute accurately to the identification of the taxa. One of the abundant taxa Mastogloia sp.1 have similar valve outline to Mastogloia elliptica (Agardh) Cleve. Nevertheless, specimens observed here lacks elliptical central area and have strongly undulated raphe in most valves. Rhopalodia acuminata specimens external valve endings were found distinctly produced. The taxa found here possibly a variety of $R$. acuminata due to the type species, have slightly produced endings (Witkowski et al., 2000; PI. 214: 24). One of the other rarely found and recorded species is Nitzschia improvisa. Taxa resemble Nitzschia prolongata Hustedt (Kaleli et al., 2017); both taxa have a similar valve outline and characteristic and could be conspecific (Witkowski et al., 2000). In the material, $N$. improvisa has narrower valves than $N$. prolongata found in the Black Sea coasts; more valves could give comparable data to distinguish two taxa precisely.

\section{CONCLUSION}

The Marine diatom database in Turkey almost only consists of planktonic forms; studies on benthic flora are rather scarce. This study brings results of the benthic diatom diversity in a coastal lake in Dalyan, and since there are few studies on marine coasts and coastal lakes, documentation of the taxa is essential to contribute to the knowledge of diatom flora of Turkey. The results of this study documented nine species recorded for the first time in Turkish diatom flora. One of the challenges of studying benthic diatoms of coastal areas, estuaries or lagoons is high biodiversity which can be mostly composed of marine and brackish tolerant species as well as some freshwater taxa. Therefore, coastal lakes and lagoons are essential habitats to determine the tolerance of diatom taxa. The results can be useful to compare the diatom species in different locations of Turkey in coastal and estuary habitats and can give ideas on the ecology of lakes and coasts in terms of the distribution of marine, marine-brackish, brackish and brackish-freshwater taxa for monitoring programmes based on benthic diatoms.

Acknowledgements: The author thanks the Turkish Ministry of Environment and Urban Planning for granting the sampling permit to Prof. Yakup Kaska, Pamukkale University. The reviewers are acknowledged for their helpful comments. The author expresses 
his gratitude Prof. Reyhan Akçaalan, Istanbul University for their comments on the manuscript, Prof. Andrzej Witkowski, University of Szczecin, Poland, Prof. Meriç Albay, Istanbul University, and Dr Cüneyt Solak, Kütahya Dumlupınar University for their assistance and valuable contributions in this research.

Conflict of Interest: No potential conflict of interest was reported by the author.

\section{REFERENCES}

Aslan, H., Gönülal, O., Can-Yılmaz, E., Elipek, B., Baytut, Ö., Tosunoğlu, M., Karabacak, E. \& Kurt, Y. (2018). Species diversity in lentic, lotic, marine and terrestrial biotopes of Gökçeada salt lake. Fresenius Environmental Bulletin, 27, 2853-2866.

Aysel, V. (2005). Check-list of the freshwater algae of Turkey, Journal of the Black Sea/Mediterranean Environment, 11, 1-124.

Başkale, E. \& Kaska, Y. (2005). Sea turtle nest conservation techniques on Southwestern beaches in Turkey. Israel Journal Zoology, 51, 13-26. [CrossRef]

Baytut, Ö. \& Gönülol, A. (2016). Phytoplankton distribution and variation along a freshwater-marine transition zone (Kızlırmak River) in the Black Sea. Oceanological and Hydrobiological Studies, 45(4), 453465. [CrossRef]

Çevik, F., Polat, S. \& Dural, M. (2008). Seasonal variations of phytoplankton in the Akyatan and Tuzla Lagoons (Adana, Turkey). Journal of Fisheries Sciences, 2, 19-29. [CrossRef]

Çolak-Sabancı, F. (2012). Taxonomic survey of benthic diatoms on natural substrata from coastal lagoon (Aegean Sea, Turkey). Turkish Journal of Fisheries and Aquatic Sciences, 12, 841-849.

Denys, L. (1997). Morphology and taxonomy of epizoic diatoms (Epiphalaina and Tursiocola) on a sperm whale (Physeter macrocephalus) stranded on the coast of Belgium. Diatom Research, 12, 1-18. [CrossRef]

Desianti, N., Belton, T. J., Thomas, R., Enache, M., Potapova, M. G., Velinsky, D. J. \& Mead, J. (2017). Sediment diatoms as environmental indicators in New Jersey Coastal Lagoons. Journal of Coastal Research, 78, 127-140. [CrossRef]

Egemen, Ö., Önen, M., Büyükışık, B., Hoşsucu, B., Sunlu, U., Gökpınar, Ş. \& Cirik, S. (1999). Ecosystem of Güllük Lagoon (Aegean Sea, Turkey). Turkish Journal of Agriculture and Forestry, 23, 927-947.

Gasparon, M. \& Burgess, J. S. (2000). Human impacts in Antarctica: traceelement geochemistry of freshwater lakes in the Larsemann Hills, East Antarctica. Environmental Geology, 39, 963-976. [CrossRef]

Giffen, M. H. (1967). III. Diatoms of the Marine Littoral Region at Kidd's Beach Near East London, Cape Province, South Africa. Nova Hedwigia, 13, 245-292.

Giffen, M. H. (1976). A further account of the marine littoral diatoms of the Saldanha Bay Lagoon, Cape Province, South Africa. Botanica Marina, 19, 379-394. [CrossRef]

Gönülol, A., Ersanlı, E. \& Baytut, Ö. (2009). Taxonomical and numerical comparison of epipelic algae from Balik and Uzun Lagoon, Turkey. Journal of Environmental Biololgy, 30, 777-784.

Guiry, M. D. \& Guiry, G. M. (2019). AlgaeBase. World-wide electronic publication, National University of Ireland, Galway. http://www. algaebase.org (Accessed 8 April 2019).

Hansson, L.-A. \& Håkansson, H. (1992). Diatom community response along a productivity gradient of shallow Antarctic lakes. Polar Biology, 12, 463-468.

Hendey, N. I. (1964). An Introductory Account of the Smaller Algae of British Coastal Waters. Part V: Bacillariophyceae (Diatoms). Fishery Investigations, Series IV. Her Majesty's Stationery Office, London, 317 pp.
Hoffman, G., Werum, M. \& Lange-Bertalot, H. (2011). Diatomeen im Süsswasser-Benthos von Mitteleuropa. A.R.G. Gantner, Ruggell, Liechtenstein.

Kaleli, M. A., Kulikovskiy, M. S. \& Solak, C. N. (2017). Some new records for marine diatom flora of Turkey from Akliman, Sinop (Black Sea). Turkish Journal of Fisheries and Aquatic Sciences, 17, 1387-1395. [CrossRef]

Kaleli, A., Krzywda, M., Witkowski, A., Riaux-Gobin, C., Solak, C. N., Zgłobicka, I., Plocinski, T., Grzonka, J., Kurzydłowski, K. J., Car, A., Desrosiers, C., Kaska, Y. \& McCartney, K. (2018). A new sediment dwelling and epizoic species of Olifantiella (Bacillariophyceae), with an account on the genus ultrastructure based on Focused Ion Beam nanocuts. Fottea, 18, 212-226. [CrossRef]

Kaska, Y., Başkale, E., Katılmış, Y., Sözbilen, D. \& Azmaz, M. (2016). Monitoring and Conservation Studies of Sea Turtles (Caretta caretta) During the 2016 Nesting Season on Muğla Sea Turtle Nesting Beaches. MacArt, Turkey.

Kociolek, J. P., Balasubramanian, K., Blanco, S., Coste, M., Ector, L., Liu, Y., Kulikovskiy, M., Lundholm, N., Ludwig, T., Potapova, M., Rimet, F., Sabbe, K., Sala, S., Sar, E., Taylor, J., Van de Vijver, B., Wetzel, C. E., Williams, D. M., Witkowski, A. \& Witkowski, J. (2019). DiatomBase. http://www. diatombase.org on 2017-08-31 (Accessed 25 March 2019).

Loir, M. \& Novarino, G. (2014). Marine Mastogloia Thwaites ex W. Smith and Stigmaphora Wallich species from the French Lesser Antilles. In A. Witkowski (Ed.), Diatom monographs 6 (pp. 1-133). Königstein: Koeltz Scientific Books.

Louvrou, I. (2007). Periphyton and its colonization in marine hydrothermal regions of island Milos (Greece). PhD Thesis, University of Athens, Greece, $447 \mathrm{pp}$.

Maraşlıoğlu, F. \& Gönülol, A. (2019). Turkish algae electronic publication. http://turkiyealgleri.hitit.edu.tr (Accessed 10 April 2019)

Margaritoulis, D., Argano, R., Baran, I., Bentivegna, F., Bradai, M. N., et al. (2003). Loggerhead turtles in the Mediterranean: present knowledge and conservation perspectives. - In: Bolten, A. B. \& Witherington, B. E. (eds), Loggerhead Sea Turtles (pp. 175-198). Washington, DC: Smithsonian Books.

Park, J. S., Lobban, C. S. \& Lee, K. W. (2018). Diatoms associated with seaweeds from Moen Island in Chuuk Lagoon, Micronesia. Phytotaxa, 351, 101-140. [CrossRef]

Peragallo, H. \& Peragallo, M. (1897-1908). Diatomees marines de France et des district maritimes voisins. M.J. Tempere, Grez sur-Loing, 491 pp. [CrossRef]

Polge, N., Sukatar, A., Soylu, E. N. \& Gönülol, A. (2010). Epipelic algal flora in the Küçükçekmece Lagoon. Turkish Journal of Fisheries and Aquatic Sciences, 10(1), 39-45. [CrossRef]

Riaux-Gobin, C. \& Compère, P. (2009). Olifantiella mascarenica gen. \& sp. nov., a new genus of pennate diatom from Réunion Island, exhibiting a remarkable internal process. Phycological Research, 57, 178-185. [CrossRef]

Seddon, A. W., Froyd, C. A. \& Witkowski, A. (2011). Diatoms (Bacillariophyta) of isolated islands: New taxa in the genus Navicula sensu stricto from the Galapagos Islands. Journal of Phycology, 47, 861-879. [CrossRef]

Sıvacı, E. R., Yardım, O., Gönülol, A., Bat, L. \& Gümüş, F. (2008). Benthic algae of Sarıkum (Sinop-Turkey) Lagoon. Journal of Fisheries Sciences, 2(4), 592-600. [CrossRef]

Simonsen, R. (1987). Atlas and catalogue of the diatom types of Friedrich Hustedt. Berlin: J. Cramer.

Snoeijs, P. (1993). Intercalibration and distribution of diatom species in the Baltic Sea, Vol. 1, The Baltic Marine Biologist Publication, 16a, Uppsala, Opulus Press, 129.

Snoeijs, P. \& Balashova N. (1998). Intercalibration and distribution of diatom species in the Baltic Sea, Vol. 5, The Baltic Marine Biologist Publication, 16e, Uppsala, Opulus Press, 144. 
Soylu, E. N., Maraşlıoğlu, F. \& Gönülol A. (2011). Epiphytic diatom flora of Liman Lake (Bafra-Samsun). Ekoloji, 20, 57-62.

Swift, E. (1967). Cleaning diatom frustules with ultraviolet radiation and peroxide. Phycologia, 6, 161-163. [CrossRef]

Şanal, M. \& Demir, N. (2018). Use of the epiphytic diatoms to estimate the ecological status of lake Mogan. Applied Ecology and Environmental Research, 16, 3529-3543. [CrossRef]
Wachnicka, A. H. \& Gaiser, E. E. (2007). Characterization of Amphora and Seminavis from south Florida, U.S.A. Diatom Research, 22, 387-455. [CrossRef]

Witkowski, A., Lange-Bertalot, H. \& Metzeltin, D. (2000). Diatom Flora of Marine Coasts I. In H. Lange-Bertalot (Ed), Iconographia Diatomologica 7 (pp. 1-925). Konigstein: Koeltz Scientific Books.

Yerli, S. (1999). Türkiye Lagünlerine Genel Bir Bakış. In A. Demirsoy (Ed.), Genel ve Türkiye Zoocoğrafyası (pp. 465-474). Ankara, Türkiye: Metaksan press. 